\title{
MADURA AWARDS DAN PERBANDINGAN PRESTASI PENDIDIKAN EMPAT KABUPATEN DI MADURA
}

\author{
Moh. Wardi \\ STAI Nazhatut Thullab Sampang \\ E-mail: mohwardi84@gmail.com
}

\begin{abstract}
Abstrak:
Islam menganjurkan kepada umatnya untuk berlomba-lomba dalam kebaikan. Penelitian menunjukan bahwa, kontestasi Kabupaten berprestasi merupakan salah satu upaya dalam mengamalkan syiar Islam diantaranya berlomba-lomba dan seruan berbuat kebaikan. Secara budaya, ajang Madura Awards menegaskan bahwa Madura bagian dari komonitas simbolis. Bagi masyarakat Madura, simbol tropi dan penghargaan menjadi daya magnet. Secara pendidikan, publikasi hasil prestasi masing-masing Kabupaten yang ada di Madura merupakan implementasi dari nilainilai perbandingan pendidikan (comparative education). Menjadi bahan evaluasi, mengetahui kekuatan dan kelemahan masingmasing Kabupaten untuk senantiasa meningkatkan kualitas dan prestasi khususnya di bidang pendidikan.
\end{abstract}

Kata kunci: Madura Awards, Prestasi pendidikan

\section{Abstract:}

Islam advocates for his people to compete in goodness. Research shows that, the contestation of achievement Regency is one of the efforts in implementing syiar Islam such as competing and calling to do good. Culturally, the Madura Awards event asserts that Madura is part of a symbolic communion. For the Madurese, symbols of trophies and awards become magnetism. In education, the publication of the achievements of each Kabupaten in Madura is an implementation of comparative education values. Being an evaluation material, know the strengths and weaknesses of each District to constantly improve the quality and achievements, especially in the field of education.

Keywords: Madura Awards, Educational achievement 


\section{Pendahuluan}

Penghujung tahun 2013, Madura menjadi topik dan opini publik bahkan sorotan lintas kalangan mulai birokrasi, akademisi, jurnalis, dan simpatisan pembaca media cetak. Terlepas dari unsur dan tujuan yang mendiskreditkan penyelenggara, dipahami bahwa Madura Awards 2013 merupakan salah satu media silaturrahmi Satuan Kerja Pemerintah Daerah empatKabupaten yang ada di Madura (Sumenep, Pamekasan, Sampang, dan Bangkalan) dalam rangka berkompetisi dibidang prestasi dan inovasi pelayanan publik yang dalam hal ini masing-masing kabupaten mendelegasikan lima kecamatan terbaiknya. Selain itu, penyelenggara yang dalam hal ini Jawa Pos Radar Madura memberikan apresiasi bagi pemenang atas kinerja pemerintah kabupaten dan kecamatan, serta memberikan motivasi kepada kabupaten dan kecamatan yang lain untuk selalu meningkatkan pelayanan yang prima kepada masyarakat.

Dipahami bahwa, penyelenggaraan Madura Award 2013 memang terilhami oleh beberapa event sebelumnya diantaranya Otonomi Award. Harian pagi Jawa Pos Radar Madura (selanjutnya disebut JPRM) merupakan salah satu koran dengan tiras terbesar di pulau madura memiliki pembaca lebih dari 25.000 orang dalam setiap harinya, sehingga memudahkan proses sosialisasi dan suksesnya program dan pelayanan publik, serta memiliki tanggung jawab untuk ikut mengawal pembangunan di pulau madura. ${ }^{1}$

Kontestasi Kabupaten berprestasi di ajang Madura Award 2013 jika dikaitkan dalam konteks agama merupakanbagian dari syiar Islam, yaitu anjuran saling berlomba-lomba dalam melakukan kebaikan,begitu juga anjuranmemberi hadiah, karena hadiah memberikan pengaruh yang positif bagi masyarakat. Bagi yang memberi,hal itu merupakan cara melepaskan diri dari sifat bakhil, sarana untuk saling menghormati, memberikan apresiasi dan dukungan moral atas jasa dan pengabdiannya. Sedangkan bagi penerima, sebagai salah satu bentuk kelapangan, evaluasi atas kinerja, jasa dan pengabdiannya yang pada gilirannya mengukuhkan ukhuwah islamiyah.

Sebagaimana fungsi hadiah sebagai alat pendidikan sangat beraneka ragam, hadiah pada dasarnya dapat berupa materi dan non materi, ${ }^{2}$ yang berupa materi seperti barang atau benda (tropi,

\footnotetext{
1 Jawa Pos Radar Madura Group, 27 November 2013.

2 Ahmad Ali Budaiwi, Imbalan dan Hukuman Pengaruhnya Bagi Pendidikan Anak, (Jakarta: Gema Insani Press, 2002), 40.
} 
dan uang) dan yang non materi seperti Pujian, perhatian, penghargaan, Berdoa, Menepuk pundak, Memberi pesan, Menjadi pendengar yang baik, kasih sayang. ${ }^{3}$

Dalam konteks pendidikan, pelaksanaan Madura Awards 2013 merupakan implementasi dari nilai-nilai perbandingan pendidikan (comparative education). Secara historis, perkembangan pendidikan suatu negara perlu melihat kemajuan pendidikan yang dicapai oleh negara lain yang lebih maju. Itulah sebabnya dalam memajukan pendidikan, suatu negara perlu membandingkannya dengan pelaksanaan pendidikan di negara lain, dalam rangka mengetahui persamaan dan perbedaannya, kelebihan dan kelemahannya, peluang dan tantangannya yang kemudian dalam bahasa orang manajemen adalah penerapan analisis SWOT (Strenght, Wekness, Opportunity dan Treatmen), ${ }^{4}$ lalu mengambil unsur positifnya sekaligus menyesuaikannya dengan kondisi lokal atau local wisdom.

Tentu saja pengalaman pendidikan suatu negara tidak dapat diaplikasikan begitu saja ke negara lain karena perbedaan budaya, politik, hukum, ekonomi, dan lainnya. Namun, pada taraf tertentu, prinsip umum yang menjiwai suatu penyelenggaraan pendidikan dapat berlaku secara global di negara lain. Adapun praktiknya bisa disesuaikan dengan negara yang bersangkutan. Yang pada akhirnya, Suatu negara menyelenggarakan pendidikan bagi bangsanya adalah dengan maksud mencerdaskan rakyat, meningkatkan pengetahuan mereka demi kesejahteraan bersama, yang pada gilirannya akan menjadikan negara itu mengalami kemajuan.

Setidaknya, dengan perbandingan pendidikan tersebut dapat tumbuh saling pengertian, saling menghargai, dan meningkatkan hubungan kerja sama antarnegara di bidang pendidikan. Terlebih ketika jarak antarnegara bukan sebuah hambatan, menjadi kian dekat karena canggihnya teknologi komunikasi dan media elektronik, yakni ketika seseorang dapat mengakses langsung via internet untuk mengetahui bagaimana kondisi pendidikan di suatu negara. Belajar dari keberhasilan pendidikan di negara lain,

3 Muhammad bin Jamil Zainu, Solusi Pendidikan Anak Masa Kini, (Jakarta : Mustaqim, 2002), 142-144.

${ }^{4}$ Rapunspel Flower, Cara Pintar Ala Einstein, Terj. Doel Wahab, (Bandung: Dar Mizan, 2007), 58. 
sehingga kita dapat memulai pembaharuan pendidikan di negara sendiri. ${ }^{5}$

Dalam konteks lokal, kontestasi Kabupaten berprestasi di ajang Madura Award 2013 merupakan ajang publikasi prestasi masing-masing Kabupaten di Maduradalam rangka mengetahui persamaan dan perbedaannya, kelebihan dan kelemahannya. Dipahami bahwa pengalaman pendidikan masing-masing Kabupaten sangat berfariasi, diakibatkan karena perbedaan kondisi sosial masyarakat, budaya, dan lainnya. Namun, pada taraf tertentu, prinsip umum yang menjiwai suatu penyelenggaraan pendidikan dapat berlaku secara umum dengan cita-cita tunggal yaitu meningkatkan mencerdaskan rakyat, kesejahteraan bersama, serta meningkatkan pengetahuan demikualitas dan prestasinya.

Dalam konteks budaya, pelaksanaan Madura Awards 2013 merupakan momentum yang mengandung dua makna. Pertama, budaya di madura bahwa substansi dari penghargaan, hadiah, dan tropi merupakan suatu yang bernilai tinggi melebihi ukuran materi yang bersifat materi (uang). Kedua, ajang Madura Awards 2013 merupakan momentum memberdayakan kelompok usaha kecil dan menengah, memperkenalkan dan mempublikasikan produk asli madura. Diantaranya batik madura, tropi Madura Awards 2013 yang merupakan produk karya seniman asal karduluk, hiburan dan musik madura yaitu ul-daul.

Fenomena menarik yang terjadi pada penghujung $2013 \mathrm{di}$ pulau Madura ini karena penyelenggaraannya masih pertama kali melaksanakan ajang Award, menarik pula untuk dikaji lebih jauh apalagi sepengetahuan peneliti, kajian ini belum dilakukan utamanya di pulau Madura.

\section{Metode Penelitian}

Penelitian ini menggunakan pendekatan kualitatif (qualitative approach) dengan metodefenomenologis. Pendekatan kualitatif merupakan prosedur penelitian yang menghasilkan data deskriptif berupa kata-kata (ucapan), tulisan, dan prilaku dari orang-orang yang diamati. ${ }^{6}$ Dalam penelitian kualitatif terdapat enam hal penting yang harus diperhatikan peneliti, yaitu: (1) menekankan pada proses, bukan pada hasil; (2) tertarik pada makna,

5 Abdurrahman Assegaf, Internasionalisasi Pendidikan; Sketsa Perbandingan Pendidikan di Negara-Negara Islam dan Barat, (Yogyakarta: Gama Media, 2003), 29.

6 Robert Bogdan dan Steven J. Taylor, Metoda Penelitian Kualitatif, (Surabaya: Usaha Nasional, 1992), 21. 
pengalaman dan struktur dalam dunia konkrit; (3) data di dekati melalui instrumen manusia; (4) melibatkan kerja lapangan, peneliti terlibat langsung, berhubungan secara fisik dengan orang, latar, lokasi atau institusi untuk mengamati, mewawancarai dan mencatat prilaku dalam latar alamiahnya; (5) menekankan pada proses, makna dan pemahaman yang didapat melalui kata-kata ataupun simbol-simbol; dan (6) proses penelitian bersifat induktif, yang peneliti konstruksikan adalah abstraksi, konsep, hipotesis dan teori berdasarkan analisis terhadap data yang mendetail.

Metode fenomenologis digunakan agar peneliti bisa mengungkap makna dibalik suatu peristiwa secara utuh. Noeng Muhadjir memberikan kriteria fenomenologis sebagai berikut; secara ontologis menuntut pendekatan holistik yang melihat objeknya dalam suatu konteks natural bukan parsial. Secara epistimologis menolak penggunaan kerangka teori sebagai langkah persiapan penelitian. Sedangkan secara aksiologis, metode fenomenologis bertumpu pada empat kriteria kebenaran, yaitu kebenaran sensual (didasarkan atas kemampuan indra), kebenaran logis (didasarkan atas ketajaman akal pikiran), kebenaran etis (didasarkan atas ketajaman akal budi), dan kebenaran transendental (yang bersumber dari wahyu Tuhan). ${ }^{7}$

Lokasi penelitian ini dilakukan di kantor Jawa Pos Radar Madura (JPRM), forum koordinasi Dewan Juri Madura Award 2013 di Hotel Camplong Sampang, serta pada malam anugerah Madura Award 2013 di Gedung Bakorwil Pamekasan. Dipilihnya lokasi ini didasari oleh suatu realitas bahwa: pertama, dilokasi ini sebagaimana dalam fokus kajian ini menyediakan data yang utuh. Kedua, sebagai alasan subjektif adalah karena keterbatasan peneliti dan demi efektifnya penelitian ini, sehingga fokus penelitian ini dibatasi pada pelaksanaan ajang Madura Award 2013.

Sumber data dalam penelitian ini bertumpu pada sumber data manusia dan non-manusia. Berkaitan dengan itu, pada bagian ini jenis datanya dibagi kedalam kata-kata dan tindakan, sumber data tertulis, foto, dan statistik. ${ }^{8}$ Sumber data manusia diperoleh dari sejumlah informan terkait, yaitu Panitia dan Dewan Juri Madura Award 2013. Pemilihan informan didasarkan atas penguasaan informan terhadap masalah penelitian. Sedangkan sumber data non-manusia berupa rangkaian dan tahapan selama

\footnotetext{
7 Noeng Muhadjir, Metodologi Penelitian Kualitatif, (Yogyakarta: Rake Sarasin, 1996), 12.

8 Lexy J. Moleong, Metodologi Penelitian Kualitatif, (Bandung: Remaja Rosdakarya, 2006), 157.
} 
Madura Award 2013 berlangsung, data-data dokumen terkait dari empat Sekretariat Kabupaten di Madura (Bangkalan, Sampang, Pamekasan, dan Sumenep).

Teknik pengumpulan data melalui pengamatan (observation) wawancara mendalam (depth interview) dan studi dokumentasi. ${ }^{9}$ Observasi merupakan langkah pokok untuk mendapatkan informasi objektif terkait fokus penelitian. Observasi dilakukan terhadap peristiwa yang berhubungan aktivitas dan rangkaian pelaksanaan Madura Award 2013. Wawancara mendalam dilakukan secara tatap muka dengan informan guna mendapatkan informasi dan gambaran yang mendalam tentang fenomena yang terjadi selama pelaksanaan Madura Award 2013.

Wawancara mengikuti model structured interview dan unstructured interview. Dengan model structured interview, wawancara dilakukan secara terstruktur sesuai dengan pedoman yang telah dipersiapkan. Selain itu wawancara juga dilakukan dengan model unstructured interview yang tidak bergantung pada pedoman wawancara, tetapi menyesuaikan dengan proses jalannya wawancara. Pertanyaan dapat berubah sesuai dengan situasi dan kondisi saat berlangsungnya wawancara. Meskipun wawancara berlangsung secara unstructured interview, peneliti berusaha tetap memfokuskan pada titik tertentu, atau disebut wawancara yang berfokus (focused interview).

Analisis data merupakan upaya mencari dan menata secara sistematis catatan hasil observasi, wawancara, dan dokumentasi untuk meningkatkan pemahaman peneliti tentang kasus yang diteliti dan menyajikannya sebagai temuan bagi orang lain. Langkah-langkah analisis data dilakukan melalui tiga tahap, pertama reduksi data, dengan membuat ringkasan-ringkasan dari catatan yang tersebar dan dengan topik yang beragam; kedua, penyajian data dari hasil penyusunan sekumpulan informasi menjadi suatu pernyataan. Data yang tersaji akan memperlihatkan hasil penelitian sementara dan menuntun langkah berikutnya untuk memahami dan menganalisisnya secara tepat; ketiga, menarik kesimpulan dan verifikasi berdasarkan hasil analisis tahapan sebelumnya.

\section{Pembahasan dan Hasil Penelitian}

\footnotetext{
9 Sugiono, Metode Penelitian Pendidikan (Pendekatan Kuantitatif, Kualitatif, dan $R \& D)$, (Bandung: Alfabeta, 2010), 309.
} 


\section{Definisi, Tujuan, Manfaat dan Pendekatan Prestasi}

Prestasi dapat di pahami sebagai hasil kerja secara kualitas dan kuantitas yang telah di capai dlam melaksanakan tugas sesuai dengan tanggungjawab yang diberikan kepadanya. ${ }^{10}$

Versi lain menyebutkan bahwa prestasi kerja adlah hasil kerja yang telah dicapai seseorang dalam melaksanakan tugas dan tanggung jawabnya yang didasarkan pada kecakapan, pengalaman, kesungguhan serta ketepatan waktu. Prestasi kerja dipengaruhi oleh tiga faktor, yaitu: (1) kemampuan dan minta; (2) kemampuan akan tugas dan perannya; (3) tingkat motivasi kerja. ${ }^{11}$

Dalam suatu teori motivasi yang dikemukakan oleh McCelland terpusat pada suatu kebutuhan yakni kebutuhan berprestasi. McCelland mengatakan bahwa manusia pada hakikatnya mempunyai kemampuan untuk berprestasi di atas kemampuan orang lain. Selanjutnya McCelland mengatakan bahwa setiap orang mempunyai keinginan untuk melakukan karya yang berprestasi atau yang lebih baik dari karya orang lain. Dalam pada itu McCelland mengatakan ada tiga kebutuhan manusia, yakni: (1) Kebutuhan untuk berprestasi; (2) Kebutuhan untuk berafiliasi; (3) Kebutuhan kekuasaan. Ketiga kebutuhan ini terbukti merupakan unsur-unsur yang amat penting dalam menentukan prestasi seseorang pekerja. ${ }^{12}$

Penilaian prestasi kerja menjadi urgen dalam suatu organisasi dan instansi, hal ini dilakukan untuk mengukur tingkat keberhasilan, kekuatan dan kelemahannya. Adapun tujuan penilaian prestasi kerja adalah: (1) untuk mengetahui tingkat prestasi; (2) pemberian imbalan yang serasi; (3) mendorong dan meningkatkan motivasi kerja. ${ }^{13}$

Selain tujuan diatas, penilaian prestasi kerja memiliki manfaat antara lain: (1) sebagai dasar evaluasi aktivitas seluruh kegiatan; (2) penghargaan dan apresiasi atas kinerja yang lalu; (3) evaluasi yang mencerminkan kekuatan dan kelemahan; (4) mengukur sejauh mana tugas dan tanggung jawabnya terealisasi; (5) sebagai dasar pengembangan institusi. ${ }^{14}$

\footnotetext{
${ }^{10}$ Anwar Prabu Mangkunegara, Evaluasi Kinerja SDM, (Bandung: Relika Aditama, 2005), 95.

11 Malayu Hasibuan, Manajemen SDM, (Jakarta: PT Bumi Aksara, 2002), 105.

12 E. Mulyasa, Manajemen Berbasis Sekolah, (Bandung: Remaja Rosdakarya, 2003), hal. 123.

13 Vetzel Rivai, Manajemen Sumber Daya Manusia Untuk Perusahaan, (Jakarta: Grafindo Persada, 2010), 311.

${ }^{14}$ Anwar Prabu Mangkunegara, Evaluasi Kinerja SDM, (Bandung: Relika Aditama, 2005), 95.
} 
Pendekatan dalam penilaian prestasi kerja, antara lain: (1) Sistem penilaian (rating system) sistem ini terdiri dari dua bagian yaitu suatu daftar karakteristik, bidang, ataupun prilaku yang akan dinilai untuk menunjukkan tingkat kinerja dari berbagai unsur. (2) Sistem peringkat (ranking system) sistem peringkat memperbandingkan sistem yang satu dengan sistem yang lain. Sistem ini bersifat kompetitif, bersaing satu sama lain dalam pengertian yang sebenarnya; (3) Sistem berdasarkan tujuan (object-based system), penilaian dengan sistem ini mengukur kinerja berdasarkan standar maupun target yang telah dirundingkan. ${ }^{15}$

Dipahami bahwa prestasi kerja ini pada dasarnya merupakan salah satu faktor penting dalam rangka meningkatkan dan mengembangkan institusi secara efektif dan efisien. Melalui penilaian ini pula sebuah institusi mengetahui bagaimana prestasi kerja mereka, dan sejauh mana hasil kerja mereka, sehingga hal ini dapat memotivasi mereka untuk kemajuan dimasa yang akan datang. Prestasi dalam organisasi/ institusi merupakan jawaban dari berhasil atau tidaknya tujuan organisasi yang telah ditetapkan.

Berkaitan dengan ini, bahwa kontestasi Kabupaten berprestasi di Madura sebagai jawaban dari kinerja semua elemen pemerintah dan masyarakat pada masing-masing Kabupaten, serta mengukur tingkat prestasi, kelebihan dan kekurangannya untuk kemajuan dimasa yang akan datang.

\section{Definisi, Tujuan dan Perbandingan Pendidikan}

Arti dari perbandingan pendidikan sebagaimana Isac Lean Kandel penulis buku Studies In Comparative Education menyatakan bahwa Perbandingan Pendidikan adalah studi tentang teori dan praktik pendidikan. Dimana objek studinya adalah teori dan praktik pendidikan itu erat kaitannya dengan sistem pendidikan yang di terapkan dinegara tersebut. Sistem pendidikan itu sendiri dipengaruhi meliputi dimensi sosial, ekonoini, ideologi, falsafah negara dan sejarah pendidikan di suatu negara. ${ }^{16}$

Versi lain Carter V. Good mengartikan bahwa lapangan studi yang mempunyai tugas untuk mengadakan perbandingan teori dan praktek pendidikan sebagaimana terdapat pada berbagai negara di luar negeri dibandingkan dengan negara sendiri. Yang tujuannya

\footnotetext{
15 Vetzel Rivai, Manajemen Sumber Daya Manusia Untuk Perusahaan, (Jakarta: Grafindo Persada, 2010), 311.

${ }^{16}$ Abdurrahman Assegaf, Internasionalisasi Pendidikan..., 27.
} 
adalah untuk meningkatkan saling pengertian dengan jalan tukarmenukar sarana pendidikan, teknik, metode, mahasiswa, guru, dosen dan teknis, dan lain-lain.

Menurut Robert F. Arnove Perbandingan Pendidikan mengkaji bagaimana negara-negara berencana memperluas, meningkatkan, dan melakukan upaya demokratisasi terhadap sistem pendidikan mereka. ${ }^{17}$

Tujuan utama dari perbandingan pendidikan tersebut adalah dapat tumbuh saling pengertian, saling menghargai, dan meningkatkan hubungan kerja sama di bidang pendidikan. Selain itu, dalam rangka mengetahui persamaan dan perbedaannya, kelebihan dan kelemahannya, yang kemudian dalam bahasa orang manajemen adalah penerapan analisis SWOT (Strenght, Wekness, Opportunity dan Treatmen). Belajar dari keberhasilan pendidikan di Negara, Provinsi, dan Kabupaten lain, sehingga kita dapat memulai pembaharuan pendidikan di Negara, Provinsi, dan Kabupaten sendiri. ${ }^{18}$

Kajian perbandingan pendidikan mengikuti prosedur ilmiah. Bagaimana seseorang atau suatu negara mengetahui teori dan praktik pendidikan di negara lain, bisa dilaksanakan dengan menerapkan teknik pengumpulan data yang sesuai dengan prosedur ilmiah. Ada beberapa metode yang bisa dipilih untuk studi perbandingan pendidikan ini. pertama, Metode Historis, Metode ini berperan untuk menemukan fakta tentang situasi pendidikan pada waktu lampau, untuk memahami pendidikan masa kini dan yang akan datang. ${ }^{19}$ Hal itu sebagaimana yang dikemukakan oleh Isaac Lean Kandel, yakni bahwa perbandingan pendidikan itu mempelajari pendidikan saat ini dengan mengingat latar belakang historisnya.

Kedua, Metode deskriptif, Bila peneliti menguraikan, menjelaskan, dan menyampaikan kondisi objektif tentang teori dan praktik pendidikan yang berupa sistem, kebijakan, proses, kurikulum, aliran, atau lainnya yang terjadi di suatu negara, maka peneliti tersebut sesungguhnya telah meimilih metode deskriptif ini. ${ }^{20}$ Metode ini mengupayakan untuk mengetahui apa saja yang ada dan bagaimana status dan fenomena itu pada masa sekarang. Van Dalen mengatakan bahwa metode deskriptif itu bukan hanya

\footnotetext{
17 Ibid

18 Ibid, 29.

19 Dudung Abdurrahman, Metode Penelitian Sejarah, (Jakarta: Logos,1999), 1.

20 Suharsimi Arikunto, Prosedur Penelitian Suatu Pendekatan Praktis (Jakarta: Rineka Cipta, 2002), 6.
} 
terbatas pada pengumpul data dan fakta secara rutin, melainkan membuat prediksi dan identifikasi hubungan antarvariabel. Metode deskriptif penting artinya bagi perbandingan pendidikan bila peneliti mampu berhadapan dan mengalami langsung situasi yang sebenarnya pendidikan di suatu negara. sasaran-sasaran tersebut ditelaah secara mendalam sebagai suatu totalitas sesuai dengan latar atau konteksnya masing-masing. ${ }^{21}$

Ketiga, Metode statistik, cara penelitian dengan menggunakan data statistik yang ada guna mengungkap atau menganalisis hubungan antar variabel penelitian tentang pendidikan di berbagai negara. Data statistik yang berhubungan dengan kependudukan, aset negara, Gross National Product (GNP), jumlah Murid, Guru, Mahasiswa, Dosen, ilmuwan, sekolah, perguruan tinggi, angka pengangguran, bahkan intensitas kriminalitas suatu masyarakat merupakan indikasi atau potret pendidikan di suatu negara. Data statistik itu sendiri masih berupa raw materials atau bahan mentah yang masih perlu diolah, dianalisis, dan diberi interpretasi oleh peneliti. ${ }^{22}$

Kelima, Metode filosofis. Filsafat disini diartikan sebagai ilmu yang menekankan karakter dan polapikir yang sistematis, radikal tentang hakikat secara tuntas. Dengan landasan filsafat ini, diharapkan bagi peneliti berusaha untuk mendapatkan prinsipprinsip dan konsep mengenai pendidikan negara-negara yang dipelajari. ${ }^{23}$ Metode ini mencoba mencermati prinsip dan konsep pendidikan yang dianut oleh suatu negara. Dalam pendidikan banyak istilah, prinsip, atau konsep yang dipakai. misalnya, penggunaan terma peserta didik, orang tua, wali murid, pendidikan kaum dewasa (adult education), pendidikan seumur hidup (long life education), penanaman nilai, dan teori pendidikan.

Keenam, Metode komparasi/ perbandingan. Dalam membandingkan, sebuah realitas sejarah dikorbankan bagi kepentingan suatu teori. Metode komparatif ini memang amat kompleks. Untuk mengurangi miss match dalam metode komparatif, pilihan terhadap unit yang diperbandingkan dalam suatu negara menurut kurun waktu tertentu atau antarnegara

21 Imron Arifin. Ed, Penelitian Kualitatif Dalam Ilmu-Ilmu Sosial dan Keagamaan (Malang: Kalimasahada Press, 1996), 57.

22 Noeng Muhadjir, Metodologi Penelitian Kualitatif (Yogyakarta: Reka Serasin, 2000), 142.

23 Imam Barnadib, Dasar-Dasar Pendidikan Perbandingan, (Yogyakarta: IP.IKIP, 1981), 43. 
dengan aspek tertentu hendaknya diseleksi agar unitnya comparable, setaraf, dan relevan.

Selanjutnya, penulis berinisiatif membandingkan prestasi antar Kabupaten di Madura (Bangkalan, Sampang, Pamekasan, dan Sumenep). Prestasi dimaksud lebih di dominasi pada sektor pendidikan, dan selebihnya pada sektor ekonomi dan kesehatan. Agar lebih sistematis, penulis sajikan dalam bentuk tabel sebagai berikut:

PRESTASI KABUPATEN BANGKALAN TAHUN 2013. ${ }^{24}$

\begin{tabular}{|c|l|l|l|}
\hline No & Rangking & $\begin{array}{c}\text { Tingkat } \\
\text { Prestasi }\end{array}$ & \multicolumn{1}{c|}{ Nama Prestasi } \\
\hline 1 & Juara I & Nasional & Piala adi bakti tani \\
\hline 2 & Juara I & Regional & Adipura ke-5 \\
\hline 3 & Juara I & Regional & Adiwiyata \\
\hline 4 & Juara I & Regional & Sepak takraw \\
\hline 5 & Juara I & Regional & Bidang tenis meja \\
\hline 6 & Juara I & Regional & Lomba koperasi berprestasi \\
\hline 7 & Juara I & Regional & Pencak silat seni putera \\
\hline 8 & Juara I & Regional & Pencak silat seni puteri \\
\hline 9 & Juara I & Regional & Lomba penyentuh teladan \\
\hline 10 & Juara I & Regional & Lomba lari SMP terbuka \\
\hline 11 & Juara I & Regional & Kelurahan berseri \\
\hline 12 & Juara I & Regional & Taman bacaan masyarakat \\
\hline 13 & Juara I & Regional & $\begin{array}{l}\text { Lomba BAP tanaman hias } \\
\text { melati }\end{array}$ \\
\hline 14 & Juara I & Regional & $\begin{array}{l}\text { Pengembangan industri } \\
\text { pangan }\end{array}$ \\
\hline 15 & Juara II & Regional & Lomba cipta B2SA \\
\hline 16 & Juara II & Regional & Lomba petugas IB \\
\hline 17 & Juara II & Regional & Dokter hewan berprestasi \\
\hline 18 & Juara II & Regional & $\begin{array}{l}\text { Lomba agribisnis tanam } \\
\text { pangan }\end{array}$ \\
\hline 19 & Juara II & Regional & $\begin{array}{l}\text { Guru, kepala, pengawas } \\
\text { berprestasi }\end{array}$ \\
\hline 20 & Juara II & Regional & $\begin{array}{l}\text { UKM pangan kategori industri } \\
\text { pangan }\end{array}$ \\
\hline
\end{tabular}

24 Dokumentasi Dewan Juri Madura Awards 2013 berdasarkan sumber data Sekretariat Kabupaten Bangkalan 01 Desember 2013. 


\begin{tabular}{|l|l|l|l|}
\hline 21 & Juara III & Regional & Kontes ternak \\
\hline 22 & Juara III & Regional & Desain batik \\
\hline 23 & Juara III & Regional & Lomba kios daging \\
\hline 24 & Juara III & Regional & $\begin{array}{l}\text { Lomba petugas paramedis } \\
\text { berprestasi }\end{array}$ \\
\hline 25 & Juara III & Regional & $\begin{array}{l}\text { Baca puisi tingkat sekolah } \\
\text { menengah }\end{array}$ \\
\hline
\end{tabular}

PRESTASI KABUPATEN SAMPANG TAHUN 2013.25

\begin{tabular}{|c|l|l|l|}
\hline No & Rangking & $\begin{array}{c}\text { Tingkat } \\
\text { Prestasi }\end{array}$ & \multicolumn{1}{|c|}{ Nama Prestasi } \\
\hline 1 & Juara I & Nasional & Piala AFR tenis Nasional \\
\hline 2 & Juara IV & Nasional & $\begin{array}{l}\text { PKH Awards pendamping dan } \\
\text { operator }\end{array}$ \\
\hline 3 & Juara I & Regional & Lompat tinggi atletik \\
\hline 4 & Juara I & Regional & Seni tunggal putra pencak silat \\
\hline 5 & Juara I & Regional & $\begin{array}{l}\text { Tilawah golongan remaja } \\
\text { puteri MTQ }\end{array}$ \\
\hline 6 & Juara I & Regional & $\begin{array}{l}\text { Tunggal putra tenis lapangan } \\
\text { porseni SD }\end{array}$ \\
\hline 7 & Juara I & Regional & $\begin{array}{l}\text { Ganda putra tenis lapangan } \\
\text { porseni SD Jatim }\end{array}$ \\
\hline 8 & Juara I & Regional & $\begin{array}{l}\text { Seni tunggal pencak silat } \\
\text { porseni SD Jatim }\end{array}$ \\
\hline 9 & Juara I & Regional & Pameran foto terbaik TAGANA \\
\hline 10 & Juara II & Regional & Lari 800 M atletik \\
\hline 11 & Juara II & Regional & Pasar tertib ukur \\
\hline 12 & Juara II & Regional & $\begin{array}{l}\text { Poomsae } \\
\text { tekwondo }\end{array}$ \\
\hline 13 & Juara II & Regional & $\begin{array}{l}\text { Tenaga kesehatan } \\
\text { teladan }\end{array}$ \\
\hline 14 & Juara II & Regional & $\begin{array}{l}\text { PKH Awards pendamping dan } \\
\text { operator }\end{array}$ \\
\hline 15 & Juara III & Regional & Regu putra catur \\
\hline 16 & Juara III & Regional & Lompat jauh atletik \\
\hline 17 & Juara III & Regional & Seni tunggal putri pencak silat \\
\hline & & & \\
\hline
\end{tabular}

25 Dokumentasi Dewan Juri Madura Awards 2013 berdasarkan sumber data Sekretariat Kabupaten Sampang 02 Desember 2013. 


\begin{tabular}{|l|l|l|l|}
\hline 18 & Juara III & Regional & $\begin{array}{l}\text { KU 16 tenis lapangan piala } \\
\text { wali kota malang }\end{array}$ \\
\hline 19 & Juara III & Regional & $\begin{array}{l}\text { UKM berprestasi kategori } \\
\text { usaha muda }\end{array}$ \\
\hline 20 & Harapan I & Regional & Gelar budaya kerja \\
\hline 21 & Harapan I & Regional & $\begin{array}{l}\text { Tilawah golongan tartil putra } \\
\text { MTQ }\end{array}$ \\
\hline 22 & Harapan I & Regional & $\begin{array}{l}\text { Tilawah golongan qiraat putra } \\
\text { MTQ }\end{array}$ \\
\hline 23 & Harapan I & Regional & $\begin{array}{l}\text { Tilawah golongan tuna netra } \\
\text { putra MTQ }\end{array}$ \\
\hline
\end{tabular}

PRESTASI KABUPATEN PAMEKASAN TAHUN 2013. ${ }^{26}$

\begin{tabular}{|c|l|l|l|}
\hline No & Rangking & \multicolumn{1}{|c|}{$\begin{array}{c}\text { Pingkat } \\
\text { Prestasi }\end{array}$} & \multicolumn{1}{|c|}{ Nama Prestasi } \\
\hline 1 & Juara I & Internasional & $\begin{array}{l}\text { Kejuaraan cabor NPC/cacat } \\
\text { Asia Tenggara }\end{array}$ \\
\hline 2 & Juara II & Internasional & $\begin{array}{l}\text { Kejuaraan cabor NPC/cacat } \\
\text { Asia Tenggara }\end{array}$ \\
\hline 3 & Juara I & Nasional & $\begin{array}{l}\text { Anugerah adhi karya pangan } \\
2013\end{array}$ \\
\hline 4 & Juara I & Nasional & Agribisnis sapi potong \\
\hline 5 & Juara I & Nasional & $\begin{array}{l}\text { penghargaan adhi bakti mina } \\
\text { bahari }\end{array}$ \\
\hline 6 & Juara I & Nasional & $\begin{array}{l}\text { Lomba informasi dan } \\
\text { konseling remaja }\end{array}$ \\
\hline 7 & Juara I & Nasional & Olimpiade fisika \\
\hline 8 & Juara I & Nasional & $\begin{array}{l}\text { Kejuaraan tennis lapangan } \\
\text { singgle putra }\end{array}$ \\
\hline 9 & Juara I & Nasional & Photography \\
\hline 10 & Juara I & Nasional & Taekwondo seri I \\
\hline 11 & Juara I & Nasional & $\begin{array}{l}\text { FLS2N seri nasional 2013 } \\
\text { pantonim }\end{array}$ \\
\hline 12 & Juara I & Nasional & $\begin{array}{l}\text { O2SN tingkat SD catur } \\
\text { perorangan putra }\end{array}$ \\
\hline 13 & Juara I & Nasional & $\begin{array}{l}\text { Kejuaraan O2SN tingkat SD } \\
\text { catur regu putra }\end{array}$ \\
\hline
\end{tabular}

26 Dokumentasi Dewan Juri Madura Awards 2013 berdasarkan sumber data Sekretariat Kabupaten Pamekasan 03 Desember 2013.

Moh. Wardi Madura Awards dan Perbandingan 


\begin{tabular}{|c|c|c|c|}
\hline 14 & Juara I & Nasional & $\begin{array}{l}\text { Kejuaraan O2SN SD catur } \\
\text { cepat beregu putra }\end{array}$ \\
\hline 15 & Juara I & Nasional & $\begin{array}{l}\text { Foto digital kategori pelajar/ } \\
\text { mahasiswa }\end{array}$ \\
\hline 16 & Juara I & Nasional & $\begin{array}{l}\text { KPDT pedesaan sehat daerah } \\
\text { tertinggal }\end{array}$ \\
\hline 17 & Juara I & Nasional & $\begin{array}{lll}\begin{array}{l}\text { Adipura } \\
\text { perkotaan }\end{array} & 2013 & \text { wilayah } \\
\end{array}$ \\
\hline 18 & Juara II & Nasional & $\begin{array}{l}\text { Penghijauan dan konservasi } \\
\text { pecinta alam }\end{array}$ \\
\hline 19 & Juara II & Nasional & $\begin{array}{l}\text { lomba menulis surat tingkat } \\
\text { remaja }\end{array}$ \\
\hline 20 & Juara II & Nasional & $\begin{array}{l}\text { Olimpiade sains nasional } \\
\text { biologi }\end{array}$ \\
\hline 21 & Juara II & Nasional & $\begin{array}{l}\text { Kejuaraan tennis lapangan } \\
\text { double putri }\end{array}$ \\
\hline 22 & Juara II & Nasional & $\begin{array}{l}\text { Kejuaraan 02SN tingkat SD } \\
\text { karate }\end{array}$ \\
\hline 23 & Juara III & Nasional & $\begin{array}{l}\text { FLS2N seri nasional } 2013 \\
\text { cipta puisi }\end{array}$ \\
\hline 24 & Juara III & Nasional & $\begin{array}{l}\text { O2SN tennis meja tunggal } \\
\text { putra }\end{array}$ \\
\hline 25 & Juara VI & Nasional & $\begin{array}{l}\text { Lomba menulis cerita tingkat } \\
\text { SMP }\end{array}$ \\
\hline 26 & Juara I & Regional & Lomba lempar lembing \\
\hline 27 & Juara I & Regional & Lomba tolak peluru \\
\hline 28 & Juara I & Regional & $\begin{array}{l}\text { Phitagoras competition } \\
\text { bidang fisika } 2013\end{array}$ \\
\hline 29 & Juara I & Regional & $\begin{array}{l}\text { Kejuaraan tennis lapangan } \\
\text { tingkat SD/SMP }\end{array}$ \\
\hline 30 & Juara I & Regional & Seni tilawah putri FLS2N \\
\hline 31 & Juara I & Regional & $\begin{array}{l}\text { Phitagoras competition } \\
\text { bidang biologi } 2013\end{array}$ \\
\hline 32 & Juara I & Regional & Lomba karate \\
\hline 33 & Juara I & Regional & $\begin{array}{l}\text { Lomba matematika tingkat } \\
\text { SMP }\end{array}$ \\
\hline 34 & Juara I & Regional & $\begin{array}{l}\text { JPIP award pelayanan } \\
\text { kesehatan }\end{array}$ \\
\hline 35 & Juara I & Regional & $\begin{array}{l}\text { Kontes sapi madura kelas } \\
\text { pedet }\end{array}$ \\
\hline 36 & Juara I & Regional & Kontes ternak sapi madura \\
\hline
\end{tabular}




\begin{tabular}{|l|l|l|l|}
\hline & & & kelas calon induk \\
\hline 37 & Juara I & Regional & $\begin{array}{l}\text { Kontes ternak sapi madura } \\
\text { kelas induk }\end{array}$ \\
\hline 38 & Juara I & Regional & $\begin{array}{l}\text { Cabor tenis meja tunggal } \\
\text { putera POR SD VI }\end{array}$ \\
\hline 39 & Juara I & Regional & Cabor bridge tingkat TK/SD \\
\hline 40 & Juara I & Regional & $\begin{array}{l}\text { Cabor NPC/cacat kelas tuna } \\
\text { grahita }\end{array}$ \\
\hline 41 & Juara I & Regional & $\begin{array}{l}\text { Cabor NPC/cacat kelas putus } \\
\text { tangan }\end{array}$ \\
\hline 42 & Juara I & Regional & $\begin{array}{l}\text { Penghijauan dan konservasi } \\
\text { pecinta alam }\end{array}$ \\
\hline 43 & Juara I & Regional & $\begin{array}{l}\text { Promosi } \\
\text { implementasi perpus }\end{array}$ \\
\hline 44 & Juara I & Regional & Pestival islam remaja/debat \\
\hline 45 & Juara I & Regional & $\begin{array}{l}\text { O2SN tennis meja tunggal } \\
\text { putra }\end{array}$ \\
\hline 46 & Juara I & Regional & O2SN pencak silat \\
\hline 47 & Juara I & Regional & Open turnament ITATS Cup \\
\hline 48 & Juara I & Regional & Lomba futsal \\
\hline 49 & Juara I & Regional & $\begin{array}{l}\text { Kecil Menanam Dewasa } \\
\text { Memanen (KMDM) }\end{array}$ \\
\hline 50 & Juara II & Regional & Agribisnis tanaman jagung \\
\hline 51 & Juara II & Regional & $\begin{array}{l}\text { Kontes ternak sapi madura } \\
\text { kelas pedet }\end{array}$ \\
\hline 52 & Juara II & Regional & $\begin{array}{l}\text { Cabor pencak silat tunggal } \\
\text { putera POR SD VI } \\
\text { Lompat tinggi tunggal putera } \\
\text { POR SD VI }\end{array}$ \\
\hline 53 & Juara II & Regional & $\begin{array}{l}\text { Implementasi budaya baca uji } \\
\text { cerdas SLTA }\end{array}$ \\
\hline 54 & Juara II & Regional \\
\hline 55 & Juara II & Regional & $\begin{array}{l}\text { Intensifikasi } \\
\text { madura }\end{array}$ \\
\hline 56 & Juara II & Regional & $\begin{array}{l}\text { Lomba matematika tingkat } \\
\text { SMP }\end{array}$ \\
\hline 57 & Juara II & Regional & Lomba Karate \\
\hline 58 & Juara II & Regional & $\begin{array}{l}\text { Lomba tekwondo } \\
\text { Go Jatim Fisika }\end{array}$ \\
\hline 59 & Juara II & Regional & $\begin{array}{l}\text { Phitagoras } \\
\text { bidang biologi 2013 }\end{array}$ \\
\hline 60 Juara III & Regional & 2013 \\
\hline
\end{tabular}




\begin{tabular}{|l|l|l|l|}
\hline 61 & Juara III & Regional & $\begin{array}{l}\text { Kader bina keluarga } \\
\text { berencana }\end{array}$ \\
\hline 62 & Juara III & Regional & Pidato kependudukan \\
\hline 63 & Juara III & Regional & Lomba fisika tingkat SMP \\
\hline 64 & Juara III & Regional & $\begin{array}{l}\text { Phitagoras competition } \\
\text { bidang biologi 2013 }\end{array}$ \\
\hline 65 & Juara III & Regional & Lomba karate \\
\hline 66 & Juara III & Regional & Lomba lari 60 meter putra \\
\hline 67 & Juara III & Regional & Open turnament ITATS Cup \\
\hline 68 & Juara III & Regional & Olimpiade fisika \\
\hline 69 & Juara III & Regional & Essay competition \\
\hline 70 & Juara III & Regional & Kajurda provinsi seri IV \\
\hline 71 & Juara III & Regional & Lomba bola volly putera \\
\hline 72 & Juara III & Regional & $\begin{array}{l}\text { Matematika, fisika, biologi, } \\
\text { bahasa inggris }\end{array}$ \\
\hline
\end{tabular}

PRESTASI KABUPATEN SUMENEP TAHUN 2013. ${ }^{27}$

\begin{tabular}{|c|l|l|l|}
\hline No & Rangking & $\begin{array}{c}\text { Tingkat } \\
\text { Prestasi }\end{array}$ & \multicolumn{1}{|c|}{ Nama Prestasi } \\
\hline 1 & Juara I & Nasional & Adipura \\
\hline 2 & Juara I & Nasional & Abdi Bhakti Tani \\
\hline 3 & Juara I & Nasional & LKTI sejarah \\
\hline 4 & Juara I & Nasional & Mushabaqah tilawatil qur'an \\
\hline 5 & Juara I & Nasional & Cipta puisi SMP \\
\hline 6 & Juara II & Nasional & Budidaya rumput laut \\
\hline 7 & Juara II & Nasional & $\begin{array}{l}\text { Petugas operasi irigasi dan } \\
\text { rawa }\end{array}$ \\
\hline 8 & Juara II & Nasional & Tahfidz al-Qur'an FLS2N \\
\hline 9 & Juara II & Nasional & Tolak peluru SMP \\
\hline 10 & Juara II & Nasional & Bola volly OS2N \\
\hline 11 & Juara III & Nasional & Forki perorangan 60 Kg putri \\
\hline 12 & Juara III & Nasional & Forki perorangan 60 Kg putra \\
\hline 13 & Juara III & Nasional & $\begin{array}{l}\text { Komite perorangan 30 Kg } \\
\text { putri }\end{array}$ \\
\hline 14 & Juara III & Nasional & $\begin{array}{l}\text { Komite perorangan 68 Kg } \\
\text { putri }\end{array}$ \\
\hline
\end{tabular}

27 Dokumentasi Dewan Juri Madura Awards 2013 berdasarkan sumber data dari Sekretariat Kabupaten Sumenep 04 Desember 2013. 


\begin{tabular}{|l|l|l|l|}
\hline 15 & Juara III & Nasional & Kata beregu U-21 senior putra \\
\hline 16 & Juara I & Regional & Jalan cepat sprint Jatim Gresik \\
\hline 17 & Juara I & Regional & UKM berprestasi \\
\hline 18 & Juara I & Regional & Desain motif batik \\
\hline 19 & Juara I & Regional & Lari 12 M POR SD Gresik \\
\hline 20 & Juara I & Regional & Lari estafet putra POR SD \\
\hline 21 & Juara I & Regional & LKTI olimpiade skill SMU \\
\hline 22 & Juara I & Regional & Kota beregu putra under 21 \\
\hline 23 & Juara I & Regional & $\begin{array}{l}\text { Duta keselamatan tingkat } \\
\text { remaja }\end{array}$ \\
\hline 24 & Juara I & Regional & Tari porseni \\
\hline 25 & Juara I & Regional & Agribisnis pertanian \\
\hline 26 & Juara I & Regional & Lembaga mandiri masyarakat \\
\hline 27 & Juara II & Regional & Tari porseni \\
\hline 28 & Juara II & Regional & $\begin{array}{l}\text { Bidang keahlian } \\
\text { aplication }\end{array}$ \\
\hline 29 & Juara II & Regional & Bola volly SMK \\
\hline 30 & Juara II & Regional & Tolak peluru putra POR SD \\
\hline 31 & Juara II & Regional & Lari 100 M putra POR SD \\
\hline 31 & Juara II & Regional & Kategori tenaga kerja \\
\hline 32 & Juara II & Regional & Hak krida pertanian \\
\hline 33 & Juara II & Regional & Tolak peluru POR SD Gresik \\
\hline 34 & Juara II & Regional & Bola volly SMK \\
\hline 35 & Juara II & Regional & Forki perorangan 68 Kg putri \\
\hline 36 & Juara II & Regional & Lomba lari jatim open \\
\hline 37 & Juara II & Regional & $\begin{array}{l}\text { Lari 60 M Matim di } \\
\text { Madiun }\end{array}$ \\
\hline 38 & Juara II & Regional & $\begin{array}{l}\text { Lari } 60 \text { M sprint jatim } \\
\text { Bangkalan }\end{array}$ \\
\hline 39 & Juara II & Regional & Komite perorangan \\
\hline 40 & Juara III & Regional & $\begin{array}{l}\text { Pelaku usaha } \\
\text { massal }\end{array}$ \\
\hline 41 & Juara III & Regional & Posyandu \\
\hline 42 & Juara III & Regional & LKTI sekolah menengah \\
\hline 43 & Juara III & Regional & Lomba secretary LKS \\
\hline 44 & Juara III & Regional & $\begin{array}{l}\text { Lari 3000 M Sprint Jatim Di } \\
\text { Sampang }\end{array}$ \\
\hline 45 & Juara III & Regional & $\begin{array}{l}\text { Lari 1000 M sprint jatim di } \\
\text { Sampang }\end{array}$ \\
\hline 46 & Juara III & Regional & $\begin{array}{l}\text { Sompat jauh sprint jatim di } \\
\text { Sampang }\end{array}$ \\
\hline
\end{tabular}




\begin{tabular}{|l|l|l|l|}
\hline 47 & Juara III & Regional & $\begin{array}{l}\text { Lari 60 M sprint jatim di } \\
\text { Sampang }\end{array}$ \\
\hline 48 & Juara III & Regional & Lempar lembing open \\
\hline 49 & Juara III & Regional & Kejurda se-Jatim putra \\
\hline 50 & Juara III & Regional & Bola volly putri porseni \\
\hline 51 & Juara III & Regional & Visualisasi fragmen \\
\hline 52 & Juara III & Regional & Kata beregu \\
\hline 53 & Nasional non rangking & $\begin{array}{l}\text { Keselamatan Kesehatan Kerja } \\
\text { (K3) RSUD }\end{array}$ \\
\hline 54 & Nasional non rangking & K3 Pegaraman I \\
\hline 55 & Nasional non rangking & K3 PT kelok mina laut \\
\hline 56 & Nasional non rangking & K3 Hotel wijaya \\
\hline 57 & Nasional non rangking & K3 Swalayan al-malik \\
\hline 58 & Nasional non rangking & K3 PDAM \\
\hline 59 & Nasional non rangking & K3 STKIP PGRI \\
\hline 60 & Nasional non rangking & K3 Hotel safari \\
\hline 61 & Nasional non rangking & K3 PT Pos \\
\hline 62 & Nasional non rangking & K3 PT Trisakti Motor \\
\hline 63 & Nasional non rangking & K3 SPBU 54.694.03 \\
\hline 64 & Nasional non rangking & K3 BPRS Bhakti Sumekar \\
\hline 65 & Nasional non rangking & $\begin{array}{l}\text { K3 koperasi karyawan PT } \\
\text { Garam }\end{array}$ \\
\hline 66 & Nasional non rangking & K3 PT Marina Indo Prima \\
\hline 67 & Nasional non rangking & K3 UD Sinar batu jaya \\
\hline 68 & Nasional non rangking & K3 CV prima mobil madura \\
\hline 69 & Nasional non rangking & K3 SPBE Gas Saronggi \\
\hline 70 & Nasional non rangking & K3 PT Key \\
\hline
\end{tabular}

Berdasarkan juknis dan pedoman penilaian yang menjadi kesepakatan Dewan Juri Madura Award 2013 bahwa sistem penilaian dari prestasi dimaksud berdasarkan tingkat jenjang,prestasi dan kesulitan dalam skala Regional, Nasional dan Internasional. Agar lebih sistematis, maka penulis membuatnya dalam bentuk tabel sebagai berikut : ${ }^{28}$

\begin{tabular}{|c|l|c|c|}
\hline No & Tingkat Jenjang & $\begin{array}{c}\text { Nilai Tingkat } \\
\text { Prestasi }\end{array}$ & $\begin{array}{c}\text { Nilai Tingkat } \\
\text { Kesulitan }\end{array}$ \\
\hline
\end{tabular}

28 Panduan kegiatan Madura Award 2013 pemilihan Kabupaten paling berprestasi, 27 November 2013. 


\begin{tabular}{|l|l|l|l|}
\hline 1 & Regional & 10 & 10 \\
\hline 2 & Nasional & 25 & 30 \\
\hline 3 & Internasional & 50 & 60 \\
\hline
\end{tabular}

Setelah melakukan koordinasi antar Dewan Juri Madura Award yang berlokasi di Hotel Camplong Sampang Madura, Dewan Juri Madura Awards 2013 memutuskan dan menetapkan bahwa Kabupaten Pamekasan menjadi pemenang kategori Kabupaten berprestasi di ajang Madura Award 2013. Dengan nilai akhir sebagaimana tabel berikut: 29

\begin{tabular}{|c|l|c|}
\hline No & Kabupaten & Nilai Akhir \\
\hline 1 & Bangkalan & 830 \\
\hline 2 & Sampang & 1370 \\
\hline 3 & Pamekasan & 4220 \\
\hline 4 & Sumenep & 3370 \\
\hline
\end{tabular}

Secara agama, kontestasi dan perlombaan dalam kebaikan, seiring dengan syiar Islam, sebagaimana Firman Allah SWT:Maka berlomba-lombalah (dalam membuat) kebaikan. di mana saja kamu berada pasti Allah akan mengumpulkan kamu sekalian (pada hari kiamat). Sesungguhnya Allah Maha Kuasa atas segala sesuatu. (QS. Al-Baqarah: 148) begitupun ditegaskan dalam surat yang lain, Maka berlomba-lombalah berbuat kebajikan. Hanya kepada Allahlah kembali kamu semuanya, lalu diberitahukan-Nya kepadamu apa yang telah kamu perselisihkan itu. (QS. Al-Maidah: 48).

Hal ini semakin menegaskan bahwa Islam senantiasa menyeru pada umatnya untuk senantiasa berlomba-lomba dalam kebaikan. Panitia dan Dewan Juri Madura Award 2013 mencoba merealisasikan dari ajaran Islam dimaksud melalui media kontestasi Kabupaten Berprestasi di ajang Madura Award 2013.30 Ditegaskan pula, bahwa Islam menghargai amal kebaikan yang kemudian disebut pahala dan hadiah. Hadiah tersebut diberikan sebab individu maupun institusi telah melakukan kebaikandan prestasi tertentu. Hadiah juga merupakan pembinaan yang dipandang sebagai proses sosial yang dapat melahirkan watak

29 Rekapitulasi akhir Dewan Juri Madura Award 2013 tanggal 24 Desember 2013.

30 Wawancara dengan Abd Aziz, (Direktur Jawa Pos Radar Madura) pada tanggal 29 Desember 2013. 
sosial dan mempunyai rasa solidaritas yang tinggi. ${ }^{31}$ Hadiah merupakan alat pendidikan yang menyenangkan, diberikan kepada yang memiliki prestasi tertentu dalam pendidikan, memiliki kemajuan dan tingkah laku yang baik sehingga dapat dijadikan teladan bagi generasi selanjutnya. ${ }^{32}$ Sejalan dengan Firman Allah SWT:

Barangsiapa yang mengerjakan kebaikan seberat dzarrahpun, niscaya Dia akan melihat (balasan)nya. (Q.S. Al-zalzalah: 7)

Dalam konteks budaya, pelaksanaan Madura Awardss 2013 merupakan penegasan bahwa substansi dari penghargaan, hadiah, dan tropi merupakan suatu yang bernilai tinggi melebihi ukuran materi (uang). Orang Madura lebih bangga dengan istilah hadiah atau tropi meskipun pada hakikatnya hadiah dan tropi dimaksud nominalnya lebih kecil ketika dimaterialkan. ${ }^{33}$ Selain itu, ajang Madura Awards 2013 merupakan momentum memberdayakan kelompok usaha kecil dan menengah, memperkenalkan dan mempublikasikan produk asli madura. Diantaranya batik madura, tropi Madura Awards 2013 yang merupakan produk karya seniman asal karduluk, hiburan dan musik madura yaitu $u l-d a u l .{ }^{34}$ Selain itu, ajang Madura Awards 2013 merupakan perekat budaya lokal Madura dengan istilah yang berfariasi silaturrahmi, temmo kerrong, antar Satuan Kerja Pemerintah Kabupaten (SKPD) di Madura. ${ }^{35}$

Selanjutnya, dalam perspektif pendidikan, kontestasi Kabupaten berprestasi di ajang Madura Awards 2013 merupakan implementasi dari perbandingan pendidikan di empat Kabupaten di Madura. Dengan adanya wadah perlombaan ini, Satuan Kerja Pemerintah Kabupaten (SKPD) bisa mengukur peta kekuatan dan kelemahan dalam berbagai sektor utamanya pada sektor pendidikan. Prestasi yang diperoleh Kabupaten Pamekasan memiliki makna dan manfaat, antara lain: pertama, menjadi indikator (simbol) kualitas maupun kuantitas yang dicapai dalam

31 Wawancara dengan Akhmadi Yasid, (Ketua Pelaksana Madura Awards 2013) pada tanggal 29 Desember 2013.

32 Wawancara dengan Amir Hamzah, (Dewan Juri Madura Awards 2013) pada tanggal 24 Desember 2013.

33 Wawancara dengan Abu Bakar Basyarahil, (Dewan Juri Madura Awards 2013) pada tanggal 24 Desember 2013.

34 Wawancara dengan Moh Harun, (Dewan Juri Madura Awards 2013) pada tanggal 24 Desember 2013.

35 Wawancara dengan Akhmadi Yasid, (Ketua Pelaksana Madura Awards 2013) pada tanggal 29 Desember 2013. 
suatu kegiatan. Kedua, pengalaman berharga dan bahan informasi untuk masa yang akan datang. ${ }^{36}$

Selain itu, bagi pemenang yaitu Kabupaten Pamekasan, merupakan apresiasi dan publikasi prestasi yang sangat membanggakan dengan nilai yang melampaui tiga kabupaten yang lain. Bahwa prestasi yang diraih Kabupaten Pamekasan merupakan rangkaian dari usaha beberapa elemen masyarakat dan pemerintah, prestasi bukanlah sesuatu yang datang tanpa usaha, namun kerja keras dan semangat yang besar yang akhirnya mengantarkan pada titik akhir yaitu the winner, dansenantiasa motivasi untuk mempertahankan bahkan meningkatkan prestasinya di masa yang akan datang. ${ }^{37}$

Selain itu, Tujuan utama dari kontestasi tersebut adalah meningkatkan hubungan kerja sama di bidang pendidikan khususnya empat Kabupaten di Madura. Mengetahui persamaan dan perbedaannya, kelebihan dan kelemahannya, meminjam istilah orang Manajemen yaitu analisis SWOT (Strenght, Wekness, Opportunity dan Treatmen). Belajar dari keberhasilan pendidikan di Kabupaten Pamekasan, sehingga kita dapat memulai dan mengaplikasikan di Kabupaten yang lain. ${ }^{38}$

\section{Penutup}

Piramida kebutuhan yang pernah di populerkan oleh Abraham maslow, senantiasa mengikuti peradaban dan perkembangan kehidupan manusia. Pertama, kebutuhan fisiologis, hal ini identik dengan kebutuhan zaman berburu dan mengumpulkan makanan. Kedua, kebutuhan keselamatan, hal ini menjadi ciri khas pada zaman pertanian. ketiga, kebutuhan memiliki, hal ini menjadi karakter masyarkat pada zaman industri. Keempat, kebutuhan penghargaan, hal ini menjadi tipe zaman pengetahuan/ informasi. kelima, kebutuhan aktualisasi diri, merupakan model dan tradisi dizaman kebijaksanaan.

Abraham Maslow memberikan inspirasi melalui teori piramida dimaksud, empat Kabupaten di Madura menjadi salah satu model pada zaman kebijaksanaan, manakala diimbangi dengan aktualisasi diri di semua sektor. Banyak orang

\footnotetext{
36 Wawancara dengan Amir Hamzah, (Dewan Juri Madura Awards 2013) pada tanggal 24 Desember 2013.

37 Wawancara dengan Abu Bakar Basyarahil, (Dewan Juri Madura Awards 2013) pada tanggal 24 Desember 2013.

38 Wawancara dengan Moh Harun, (Dewan Juri Madura Awards 2013) pada tanggal 24 Desember 2013.
} 
menghubungkan prestasi dengan berbagai penghargaan, namun hakikat dari prestasi adalah pengakuan dan aktualisasi diri. Bahwa kerja keras yang dilakukannya telah mendapat pengakuan dan dipublikasikan di Madura Awards 2013.

Berdasarkan penelitian diatas, maka peneliti merekomendasikan dalam rangka meningkatkan prestasi. Antara lain: pertama, kerja keras yang diartikan sebagai suatu tindakan dan perbuatan yang dilakukan pemerintah dan unsur masyarakat dengan sungguh-sungguh sampai tercapai tujuan.Kedua, disiplin, tekun dan rajin yang diartikan sebagai tindakan yang bermanfaat dalam belajar, menghargai waktu dan rutinitas latihan dalam mengerjakan sesuatu. Ketiga, percaya diri dan sikap optimis, yaitu keselarasan dan keseimbangan antara kemampuan dan ikhtiar yang menumbuhkan keyakinan pada diri sendiri.

\section{Daftar Pustaka}

Abdurrahman, Dudung. Metode Penelitian Sejarah. (Jakarta: Logos, 1999)

Arifin, Imron. Ed, Penelitian Kualitatif Dalam Ilmu-Ilmu Sosial dan Keagamaan. (Malang: Kalimasahada Press, 1996)

Arikunto, Suharsimi. Prosedur Penelitian Suatu Pendekatan Praktis. (Jakarta: Rineka Cipta, 2002)

Assegaf, Abdurrahman. Internasionalisasi Pendidikan; Sketsa Perbandingan Pendidikan di Negara-Negara Islam dan Barat. (Yogyakarta: Gama Media, 2003)

Barnadib, Imam. Dasar-Dasar Pendidikan Perbandingan. (Yogyakarta: IP.IKIP, 1981)

Bogdan, Robert dan Steven J. Taylor, Metoda Penelitian Kualitatif. (Surabaya: Usaha Nasional, 1992)

Budaiwi, Ahmad Ali. Imbalan dan Hukuman Pengaruhnya bagi Pendidikan Anak. (Jakarta: Gema Insani Press, 2002)

Dokumentasi Dewan Juri Madura Awards 2013 berdasarkan sumber data Sekretariat Kabupaten Bangkalan 01 Desember 2013.

Dokumentasi Dewan Juri Madura Awards 2013 berdasarkan sumber data Sekretariat Kabupaten Sampang 02 Desember 2013.

Dokumentasi Dewan Juri Madura Awards 2013 berdasarkan sumber data Sekretariat Kabupaten Pamekasan 03 Desember 2013. 
Dokumentasi Dewan Juri Madura Awards 2013 berdasarkan sumber data dari Sekretariat Kabupaten Sumenep 04 Desember 2013.

Flower, Rapunspel. Cara Pintar Ala Einstein, Terj. Doel Wahab. (Bandung: Dar Mizan, 2007)

Hasibuan, Malayu. Manajemen SDM. (Jakarta: PT Bumi Aksara, 2002)

J. Moleong, Lexy Metodologi Penelitian Kualitatif. (Bandung: Remaja Rosdakarya, 2006)

Jawa Pos Radar Madura Group, 27 November 2013.

Mangkunegara, Anwar Prabu. Evaluasi Kinerja SDM. (Bandung: Relika Aditama, 2005)

Muhadjir, Noeng Metodologi Penelitian Kualitatif. (Yogyakarta: Reka Serasin, 2000)

Mulyasa, E. Manajemen Berbasis Sekolah. (Bandung: Remaja Rosdakarya, 2003)

Panduan kegiatan Madura Award 2013 pemilihan Kabupaten paling berprestasi, 27 November 2013.

Rekapitulasi akhir Dewan Juri Award 201324 Desember 2013.

Rivai, Vetzel. Manajemen Sumber Daya Manusia Untuk Perusahaan.

(Jakarta: Grafindo Persada, 2010)

Sugiono, Metode Penelitian Pendidikan (Pendekatan Kuantitatif, Kualitatif, dan R\&D. Bandung: Alfabeta, 2010)

Wawancara dengan Abd Aziz, (Direktur Jawa Pos Radar Madura) pada tanggal 29 Desember 2013.

Wawancara dengan Abu Bakar Basyarahil, (Dewan Juri Madura Awards 2013) pada tanggal 24 Desember 2013.

Wawancara dengan Akhmadi Yasid, (Ketua Pelaksana Madura Awards 2013) pada tanggal 29 Desember 2013.

Wawancara dengan Amir Hamzah, (Dewan Juri Madura Awards 2013) pada tanggal 24 Desember 2013.

Wawancara dengan Moh Harun, (Dewan Juri Madura Awards 2013) pada tanggal 24 Desember 2013.

Zainu, Muhammad bin Jamil. Solusi Pendidikan Anak Masa Kini. (Jakarta: Mustaqim, 2002) 